\title{
IMPACT OF TIME ON SHORT TERM OUTCOME FOR PERCUTANEOUS CORONARY INTERVENTION AFTER FAILED FIBRINOLYSIS FOR STEMI PATIENTS
}

\author{
By \\ Mohamed Abd El-Mohsen, Mamdouh Al-Tahan, Youssef Nosir, \\ Mohamed A. Mosaad and Ashraf A. Abd El-Monem \\ Cardiology and Clinical Pathology Department, Al-Azhar University, Cairo, Egypt \\ *Corresponding author: Mohamed abdelmohsen, Al-Azhar University-Faculty of \\ medicine and Nasser Institute hospital, Aghakhan shoubra misr, Shoubra, Cairo, Egypt
}

\begin{abstract}
Background: Although primary percutaneous coronary intervention (PPCI) is the most preferred reperfusion strategy for ST-segment-elevation in myocardial infarction (STEMI), fibrinolytic therapy is considered a valid alternative when PPCI is not feasible or cannot be done within 1 hour after the first medical contact.

Objective: To assess the short-term outcome of anterior STEMI patients after failed fibrinolytic therapy, undergoing rescue PCI at 3 different timing scenarios, and to study the effect of delayed intervention on the outcome.

Patients and Methods: This study included 63 patients with a diagnosis of anterior STEMI admitted to CCU in Nasser Institute hospital and Sayed Galal University Hospital from December 2016 to August 2018. They received thrombolysis by using streptokinase (1.500.000 IU) without clinical and/or electrocardiographic evidence of successful reperfusion within 90 minutes after the start of fibrinolysis. Patients were referred for rescue PCI within 24 hours. Patients were divided according to time delay from rescue PCI into 3 equal groups: Group A had PCI 3-6 hours after failed thrombolysis, group B had PCI 6-12 hours after failed thrombolysis and group C had PCI 12-24 hours after failed thrombolysis. Patients were studied for the incidence of major adverse cardiac events (MACE), i.e. death; reinfarction, target vessel revascularization (TVR), rehospitalization, symptomatic heart failure and LVEF in the acute stage and after 3 months follow up as primary end points. Left ventricular performance and viability were followed up using low dose dobutamine stress echocardiography as secondary endpoints.
\end{abstract}

Results: Total 63 patients enrolled in the study with mean age $58.60 \pm 10.42$ years. $84.1 \%$ were males and $15.9 \%$ were females. Diabetic patients were $65 \%$, hypertensives and smokers were $65 \%$ and $42.9 \%$ respectively. All patients underwent rescue PCI with bare metal stents (BMS). Three months follow up showed that group A patients had the lowest incidence of MACE $(0.0 \%$ for Death, reinfarction, TVR, rehospitalization, and highest mean EF 54.14 \pm 6.80 (40 - 65) followed by group B (4.7\% for death, $9.5 \%$ for

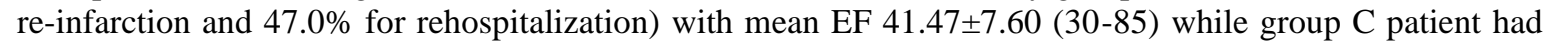
the highest MACE rates and lowest mean LVEF 34.64 $\pm 5.60(20$ - 40). There was non-significant increase in mortality and TVR rate between the 3 groups. Re-hospitalization showed a statistically significant difference that increased from $0 \%$ in group A to $47.0 \%$ in group B and $66.6 \%$ in group C. Concerning viability assessed by low dose DSE, there were significant difference between groups. In group A, only $4.7 \%$ had non-viable infarcted related area, while this percentage increased in group B and C to $38.0 \%$ and $100 \%$ respectively.

Conclusion: Rescue PCI should be done as early as possible for favorable clinical outcome.

Keywords: Thrombolytic Therapy; Myocardial Infarction; Death; Dobutamine stress echocardiography. 


\section{INTRODUCTION}

STEMI occurs due to an acute occlusion of an infarct-related artery (IRA) that can cause irreversible ischemia-induced myocardial necrosis within $20-60 \mathrm{~min}$ of onset. Untreated STEMI patients have higher mortality and poor clinical outcomes compared to those who receive a reperfusion strategy (Farshid et al., 2016).

The mainstay of STEMI management is rapid intervention aimed at relieving the IRA thrombotic obstruction and thus reducing infarct size, preserving left ventricular function, and decreasing morbidity and mortality. In the 1980s, fibrinolysis became the standard means to achieve reperfusion. Subsequently, a number of randomized trials and metaanalyses showed that primary PCI (PPCI), when performed rapidly, was associated with improved clinical outcomes compared to fibrinolytic therapy (Rosselló et al., 2017).

However, the mortality benefit of primary PCI is reduced with treatment delays, with no benefit observed when the difference between time of fibrinolysis and time of PCI exceeds $115 \mathrm{~min}$ (Chakrabarti et al., 2012).

Current guidelines recommend the use of fibrinolytic therapy when the time from first medical contact to PCI is anticipated to be greater than $120 \mathrm{~min}\left(O^{\prime}\right.$ Gara et al., 2013).

Despite these recommendations, data from the US National Cardiovascular Data Registry showed that only $51 \%$ of STEMI patients transferred for primary PCI achieved the recommended first door-to- balloon time of <120 min (Vora et al., 2015).

The present work aimed to perform a comparative analysis of three months follow up in patients have rescue PCI performed at three different time intervals after failed thrombolytic therapy as regards in-hospital complications, 3 months post discharge MACE; all-cause mortality, re- infarction, heart failure, target vessel revascularization, lifethreatening bleeding (primary endpoints). Left ventricular (LV) myocardial viability using low dose dobutamine stress echocardiography (DSE) after three months (secondary endpoints).

\section{PATIENTS AND METHODS}

This study was conducted at the cardiology department of Nasser Institute hospital-Cairo, and Sayed Galal hospital (Al-Azhar University Hospital) comprised 63 patients who presented to the emergency department during the period from December 2016 to August 2018.

Patients were eligible for enrollment in the study if they presented with anterior STEMI on their qualifying ECG with unequivocal changes $(\geq 0.1 \mathrm{mV}$ of STsegment elevation in the precordial leads V1-V6 with or without lateral leads I and aVL or new pathological $Q$ waves) on surface electrocardiogram on admission. PPCI couldn't be done within 1 hour from admission, received thrombolytic therapy streptokinase (1.500.000 IU over 30-60 mins) without clinical and or electrocardiographic evidence of successful reperfusion 90 minutes after start of fibrinolysis (less than $50 \%$ regression in the ST segment elevation in the leads with maximum ST elevation 
and/or persistence or worsening of chest pain with no contraindication for either thrombolytic therapy and PCI.

Transthoracic echocardiography was performed at baseline and after 3 months for comparison between LVEF and extent of CAD using 17 segments model and the 5-score wall motion score index (WMSI). Each segment is given a score based on its systolic function (normal $=1$, hypokinesis $=2$, akinesis $=3$, dyskinesis $=4$, Aneurysm=5). The index (WMSI) was calculated by dividing the total of the wall motion scores of each segment by 17 . A WMSI of $1.0(17 / 17)$ is considered normkinetic and correlates with a CMRI calculated ejection fraction of $64 \%$, whereas a WMSI of 3.0 correlates with an ejection fraction of $12 \%$ and is considered akinetic. WMSIs of $1.5,2.0$, and 2.5 are designated mild hypokinesia, hypokinesia, and severe hypokinesia, respectively. In addition, low dose dobutamine stress echocardiography (DSE) was performed after 3 months for all patients to study LV myocardial viability (secondary endpoints).

Patients were excluded if underwent PPCI, had significant multiple lesions in different epicardial artery or chronic total occlusion (CTO), had previous MI, or if they had cardiogenic shock at presentation (systolic blood pressure $<80 \mathrm{~mm} \mathrm{Hg}$, unresponsive to fluids, or necessitating catecholamines), patients with any contraindications to aspirin, clopidogrel or allergic to the dye, inability to comply with study procedures; and unwillingness to provide written informed consent to participate in this study.
Patients were divided into 3 equal groups according to the time of rescue PCI post failed fibrinolysis into:

- Group A: 3-6 hours.

- Group B: >6-12 hours.

- Group C: >12-24 hours.

\section{Statistical analysis:}

The collected data were revised, coded, tabulated, and computed by using Statistical package for the Social Science (SPSS) version 20.0 for windows (SPSS Inc., Chicago, IL, USA). Data was presented and suitable analysis was done according to the type of data obtained for each parameter. Quantitative data were expressed as mean \pm standard deviation (SD) and ranges. Qualitative data were expressed as frequency and percentage when parametric and median with interquartile range (IQR) when nonparametric and percentiles were used to assess the distribution of some parameters. Also, qualitative variables were presented as number and percentages. Analytical statistics: ANOVA test was used to assess the statistical significance of the difference between more than two study group means. Post Hoc Test; Least Significant Difference (LSD) was used for multiple comparisons between different variables. Chi-Square test $\left(\mathrm{x}^{2}\right)$ and/or Fisher exact test were used to examine the relationship between two qualitative variables. Kruskal-Wallis test used when the normality, homogeneity of variances, or outliers' assumptions for One-Way ANOVA are not met. Wilcoxon signedrank test is the nonparametric test equivalent to the dependent t-test while the comparison between two paired groups regarding quantitative data with 
parametric distribution was done by using Paired t-test. It is used to compare two sets of scores that come from the same participants. This can occur when we wish to investigate any change in scores from one time point to another, or when individuals are subjected to more than one condition.

P- value level of significance:wos $<0.05$ :

\section{RESULTS}

The demographic data of the recruited patients subgroups (A, B and C) according to time elapsed from failed thrombolysis till rescue PCI were expressed as mean \pm $\mathrm{SD}$ and presented in Table (1).

Total 63 patients included in the study with mean age $58.60 \pm 10.42$ years, $84.1 \%$ were male and $15.9 \%$ were female. Diabetic patients were $65 \%$, hypertensives and smokers were $65 \%$ and $42.9 \%$ respectively. All groups were matched as regards the demographic data and the risk factors.

Table (1): Comparison between the studied groups according to demographic data

\begin{tabular}{|c|c|c|c|c|}
\hline $\begin{array}{c}\text { Groups } \\
\text { Basic Characteristics }\end{array}$ & $\begin{array}{c}\text { Group A } \\
(21)\end{array}$ & $\begin{array}{c}\text { Group B } \\
(21)\end{array}$ & $\begin{array}{c}\text { Group C } \\
(21)\end{array}$ & P-value \\
\hline \multicolumn{5}{|l|}{ Age (Years) } \\
\hline $\begin{array}{l}\text { Mean } \pm \text { SD } \\
{[\min -\max ]}\end{array}$ & $\begin{array}{l}60 \pm 10.3 \\
{[36-72]} \\
\end{array}$ & $\begin{array}{l}58 \pm 10.1 \\
{[37-72]} \\
\end{array}$ & $\begin{array}{l}59 \pm 9.6 \\
{[39-72]}\end{array}$ & $>0.05$ \\
\hline \multicolumn{5}{|l|}{ Gender } \\
\hline Gender (Male) & $17(81 \%)$ & $18(85.7 \%)$ & $18(75 \%)$ & \multirow{2}{*}{$>0.05$} \\
\hline Gender (Female) & $4(19 \%)$ & $3(14.3 \%)$ & $3(14.3 \%)$ & \\
\hline \multicolumn{5}{|l|}{ Risk factors } \\
\hline Diabetes & $14(66.7 \%)$ & $11(52.4 \%)$ & $16(66.7 \%)$ & $>0.05$ \\
\hline Hypertension & $13(61.9 \%)$ & $11(52.4 \%)$ & $17(70.8 \%)$ & $>0.05$ \\
\hline Smoking & $10(47.6 \%)$ & $9(42.9 \%)$ & $8(33.3 \%)$ & $>0.05$ \\
\hline $\begin{array}{l}\text { Heart rate } \\
\text { Mean } \pm \text { SD } \\
\text { (Min-Max) }\end{array}$ & $\begin{array}{c}100 \pm 5.3 \\
{[60-110]}\end{array}$ & $\begin{array}{c}90 \pm 7.2 \\
{[80-105]}\end{array}$ & $\begin{array}{l}100 \pm 14.7 \\
{[66-120]}\end{array}$ & $>0.05$ \\
\hline $\begin{array}{l}\text { Total cholesterol (mg/DI) } \\
\text { Mean } \pm \text { SD }\end{array}$ & $191 \pm 40$ & $192 \pm 42$ & $191 \pm 37$ & $>0.05$ \\
\hline $\begin{array}{l}\text { LDL-C (mg/Dl) } \\
\text { Mean } \pm \text { SD }\end{array}$ & $121 \pm 36$ & $119 \pm 34$ & $122 \pm 37$ & $>0.05$ \\
\hline $\begin{array}{l}\text { HDL-C (mg/Dl) } \\
\text { Mean } \pm \text { SD }\end{array}$ & $38 \pm 1038$ & $38 \pm 11$ & $39 \pm 9$ & $>0.05$ \\
\hline $\begin{array}{l}\text { Triglyceride (mg/DI) } \\
\text { Mean } \pm \text { SD }\end{array}$ & $179 \pm 95$ & $194 \pm 123$ & $169 \pm 74$ & $>0.05$ \\
\hline \multicolumn{5}{|c|}{ Time from failed fibrinolysis till rescue PCI (Hours) } \\
\hline $\begin{array}{l}\text { Mean } \pm \text { SD } \\
{[\text { min-max] }}\end{array}$ & $\begin{array}{c}4 \pm 1.9 \\
{[3-6]} \\
\end{array}$ & $\begin{array}{c}10 \pm 1.5 \\
{[3-6]} \\
\end{array}$ & $\begin{array}{c}10 \pm 1.5 \\
{[7-12]} \\
\end{array}$ & $\begin{array}{l}17 \pm 5.6 \\
{[13-24]}\end{array}$ \\
\hline
\end{tabular}

$\mathrm{K}=$ Kruskal-Wallis test, $\mathrm{F}=$ Fisher's exact test,

$\mathrm{C}=$ Chi-Square test 
Comparing the $\mathrm{EF} \%$ at presentation (After lytic therapy and before rescue PCI) and after 3 months follow up are expressed as mean $\pm \mathrm{SD}$ and presented in Table (2).

There was no statistically significant difference with a mean $\mathrm{EF}$ equal to $35.5 \%$ in groups $\mathrm{A}$ and $\mathrm{B}$ and $34.04 \%$ in group C (p-value $>0.05)$.

After 3 months follow up there was high significant difference between group $\mathrm{A}$ and group B as well as between group $A$ and group $C$ and significant difference between group $\mathrm{B}$ and group $\mathrm{C}$, as the mean $\mathrm{EF} \%$ in group A increased from $35.47 \%$ to $54.14 \pm 6.80 \%$ and in group B from $35.51 \%$ to $41.47 \pm 7.60 \%$ whereas in group $\mathrm{C}$ showed no significant difference in $\mathrm{EF} \%$ at presentation and after 3 months follow up with mean $\mathrm{EF} \% 34.64 \pm 5.60 \%$.

Comparing the $\mathrm{EF} \%$ at presentation and after 3 months follow up among each group showed a highly significant difference of $\mathrm{EF} \%$ before and after 3 months follows up in group $A$ and significant difference in group B but no significant difference in group $\mathrm{C}$.

Table (2): Comparison of the EF\% at presentation and after 3 months follow up using ANOVA test

\begin{tabular}{|c|c|c|c|c|}
\hline EF\% & $\begin{array}{c}\text { Group A } \\
{[0-06 \mathrm{hr}]} \\
(\mathbf{n = 2 1})\end{array}$ & 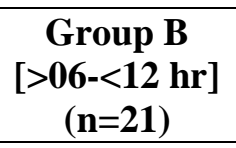 & $\begin{array}{c}\text { Group C } \\
{[>12 \mathrm{hr}]} \\
(\mathbf{n}=\mathbf{2 1})\end{array}$ & $\begin{array}{c}\text { p- } \\
\text { value }\end{array}$ \\
\hline Mean \pm SD & $35.47 \pm 3.72$ & $35.51 \pm 4.11$ & $34.04 \pm 4.81$ & \multirow{2}{*}{$>0.05$} \\
\hline Range & $30-43$ & $30-45$ & $25-40$ & \\
\hline \multicolumn{5}{|c|}{ EF\% after 3 months } \\
\hline Mean \pm SD & $54.14 \pm 6.80$ & $41.47 \pm 7.60$ & $34.64 \pm 5.60$ & \multirow{6}{*}{$<0.001$} \\
\hline Range & $40-65$ & $30-58$ & $20-40$ & \\
\hline Post HOC test & & & & \\
\hline Group A & & $<0.001$ & $<0.001$ & \\
\hline Group B & & & 0.007 & \\
\hline Group C & & & --- & \\
\hline $\begin{array}{l}\text { EF at } \\
\text { presentation } \\
\text { and after } 3 \\
\text { months among } \\
\text { each group }\end{array}$ & $\begin{array}{c}\text { Group A } \\
{[0-06 \mathrm{hr}]} \\
(\mathbf{n}=21)\end{array}$ & $\begin{array}{c}\text { Group B } \\
{[>6-<12 \mathrm{hr}]} \\
(\mathrm{n}=21)\end{array}$ & \multicolumn{2}{|c|}{$\begin{array}{c}\text { Group C } \\
(>12 \mathrm{hr}](\mathrm{n}=\mathbf{2 1})\end{array}$} \\
\hline $\begin{array}{l}\text { EF\% at } \\
\text { presentation } \pm S D\end{array}$ & $35.47 \pm 3.72$ & $35.51 \pm 4.11$ & \multicolumn{2}{|c|}{$34.04 \pm 4.81$} \\
\hline $\begin{array}{l}\text { EF\% after } 3 \\
\text { months } \pm \text { SD }\end{array}$ & $52.95 \pm 7.21$ & $41.47 \pm 7.60$ & \multicolumn{2}{|c|}{$34.64 \pm 5.60$} \\
\hline Mean difference & 17.48 & 5.960 & \multicolumn{2}{|c|}{1.611} \\
\hline p-value & $<0.0001$ & 0.003 & \multicolumn{2}{|c|}{$>0.05$} \\
\hline
\end{tabular}

Wilcoxon signed-rank test

p-value $>0.05 \mathrm{NS}$; p-value $<0.05 \mathrm{~S}$; p-value $<0.001 \mathrm{HS}$

Concerning bleeding there were nonsignificant difference as regards life threatening bleeding in acute stage nor stroke but the minor bleeding showed significant difference (p-value 0.01) between the 3 groups with highest percentage was in group A $(47.6 \%)$ compared to groups B and C $(28.5 \%$ and $14.2 \%$ ) respectively (Table 3 ). 
Table (3): Comparison between the studied groups as regarding life threatening bleeding, minor bleeding and stroke by Kruskal-Wallis test and fisher's exact test

\begin{tabular}{|l|c|c|c|c|}
\hline & Group A & Group B & Group C & P-value \\
\hline \multicolumn{4}{|l|}{ Life threatening bleeding in acute stage } \\
\hline Mean (\%) & $2(9 \%)$ & $1(4 \%)$ & $1(4 \%)$ & $>0.05$ \\
\hline Minor bleeding & $6(28.5 \%)$ & $3(14.2 \%)$ & $<0.01^{*}$ \\
\hline Mean (\%) & $10(47.6 \%)$ & & $1(4 \%)$ & $>0.05$ \\
\hline Stroke & $0(0 \%)$ & $0(0 \%)$ & \\
\hline Mean (\%) &
\end{tabular}

$\mathrm{K}=$ Kruskal-Wallis test

$\mathrm{F}=$ Fisher's exact test

p-value $>0.05 \mathrm{NS}$; p-value $<0.05 \mathrm{~S}$

During angiography there were statistically highly significant differences regarding final TIMI flow (after intervention) with highest percentage of
TIMI flow III in Group A \& B and least in Group $C$ that had the highest percent TIMI flow 0 at the end of the procedure (Table 4).

Table (4): Comparison between groups regarding TIMI flow grade

\begin{tabular}{|c|c|c|c|c|c|}
\hline & & \multicolumn{3}{|c|}{} & P-value \\
\hline & & $\mathrm{A}$ & $\mathrm{B}$ & $\mathrm{C}$ & \\
\hline \multirow{4}{*}{ TIMI flow Grade } & 0 & $3.00 \%$ & $12.00 \%$ & $47.00 \%$ & $<0.001$ \\
\cline { 2 - 6 } & I & $2.00 \%$ & $6.00 \%$ & $4.00 \%$ & $>0.05$ \\
\cline { 2 - 6 } & II & $11.00 \%$ & $17.00 \%$ & $33.00 \%$ & 0.005 \\
\cline { 2 - 6 } & III & $84.00 \%$ & $65.00 \%$ & $16.00 \%$ & $<0.001$ \\
\hline
\end{tabular}

p-value $>0.05 \mathrm{NS}$; *p-value $<0.05 \mathrm{~S}$; **p-value $<0.001 \mathrm{HS}$

After 3 months follow up there was non-significant increase in mortality and TVR rate between the 3 groups. Whereas the re-hospitalization increased significantly from $0 \%$ in group $\mathrm{A}$ to $47.0 \%$ in group B and $66.6 \%$ in group C.

Rehospitalization due to symptomatic heart failure was $68.1 \%$ and while $31.8 \%$ was for acute coronary syndrome (ACS).

The mechanical complications; VSR, significant $M$, pericardial effusion and negative remodeling with LV aneurysm are expressed as the percentage of total as well as each mechanical complication in each group. There were no mechanical complications in group A 0\% compared with group B $4.2 \%$ and group C $28.5 \%$

Myocardial viability is expressed as the percentage $(\%)$ of patients with viable as well as non-viable infarct related (IR) myocardium in each group. There was a high significant difference between groups (p-value <0.001).

As in group A only $4.7 \%$ had nonviable infarct related (IR) myocardium while this percentage increased in group B and $\mathrm{C}$ to $38.0 \%$ and $100 \%$ respectively

Comparing the outcome between each group as regards mortality there was no statistically significant difference, 3 patients died at 3 months follow up. One in group $\mathrm{A}$ and 2 patients in group $\mathrm{C}$. Comparing between groups $\mathrm{A} \& \mathrm{~B}$, there was statistically significant difference as regards symptomatic heart failure only. While comparing between group $\mathrm{A} \& \mathrm{C}$ there was statistically significant difference in all clinical parameters as symptomatic heart failure, rehospitalization as well as reinfarction 
and TVR with highest percentage of cases in group $\mathrm{C}$ patients. There were also statistical high significant differences between groups $\mathrm{B} \& \mathrm{C}$ regarding symptomatic heart failure and no significant difference regarding the other studied parameters of clinical outcome. (Table 5).

Table (5): Comparison between the studied groups regarding outcome after three months by Chi-square test

\begin{tabular}{|c|c|c|c|c|c|}
\hline Outcome & $\begin{array}{c}\text { Group A } \\
{[0-6 \mathrm{hr}]} \\
(\mathrm{n}=21)\end{array}$ & $\begin{array}{l}\text { Group B } \\
{[>06-<12} \\
\text { hr] }(\mathrm{n}=\mathbf{2 1})\end{array}$ & $\begin{array}{c}\text { Group C } \\
{[>12 \mathrm{hr}]} \\
(\mathbf{n = 2 1})\end{array}$ & $\mathbf{x} 2$ & p-value \\
\hline Total mortality & $0(0.0 \%)$ & $1(4.7 \%)$ & $2(9.5 \%)$ & 2.10 & $>0.05$ \\
\hline Reinfarction & $0(0.0 \%)$ & $2(9.5 \%)$ & $5(23.8 \%)$ & 6.107 & 0.047 \\
\hline Rehospitalization & $0(0.0 \%)$ & $8(47.0 \%)$ & $14(66.6 \%)$ & 20.674 & $<0.001$ \\
\hline TVR & $0(0.0 \%)$ & $2(9.5 \%)$ & $4(19.0 \%)$ & 4.42 & $>0.05$ \\
\hline ISR & $0(0.0 \%)$ & $2(5.9 \%)$ & $3(14.2 \%)$ & 3.04 & $>0.05$ \\
\hline $\begin{array}{c}\text { Same target } \\
\text { vessel (No ISR) }\end{array}$ & $0(0.0 \%)$ & $(0.0 \%)$ & $1(4.7 \%)$ & 2.032 & $>0.05$ \\
\hline $\begin{array}{l}\text { Another vessel } \\
\text { (Not target) }\end{array}$ & $0(0.0 \%)$ & $(0.0 \%)$ & $1(4.7 \%)$ & 2.032 & $>0.05$ \\
\hline Unstable Angina & $0(0.0 \%)$ & $1(4.7 \%)$ & $0(0.0 \%)$ & 2.032 & $>0.05$ \\
\hline Symptomatic HF & $0(0.0 \%)$ & $4(19.0 \%)$ & $11(52.3 \%)$ & 16.275 & $<0.001$ \\
\hline \multicolumn{6}{|c|}{ Mechanical complications (MCs) } \\
\hline Total MCs & $0(0.0 \%)$ & $1(4.8 \%)$ & $9(42.8 \%)$ & 17.354 & $<0.001$ \\
\hline LV Aneurysm & $0(0.0 \%)$ & $0(0.0 \%)$ & $4(19.0 \%)$ & 8.54 & 0.013 \\
\hline $\begin{array}{c}\text { Pericardial } \\
\text { Effusion }\end{array}$ & $0(0.0 \%)$ & $0(0.0 \%)$ & $1(4.8 \%)$ & 2.032 & $>0.05$ \\
\hline Significant MR & $0(0.0 \%)$ & $1(4.8 \%)$ & $3(14.3 \%)$ & 3.373 & $>0.05$ \\
\hline VSR & $0(0.0 \%)$ & $0(0.0 \%)$ & $1(4.8 \%)$ & 2.032 & $>0.05$ \\
\hline \multicolumn{6}{|c|}{ Viability after three months } \\
\hline Non-viable & $1(4.7 \%)$ & $8(38.0 \%)$ & $21(100 \%)$ & 22.933 & $<0.0001$ \\
\hline
\end{tabular}

Mortality: Group A vs B (p-value 0.311); Group A vs C (P-value 0.147); Group B vs C (P-value 0.549).

Reinfarction: Group A vs. B (p-value 0.147); Group A vs. C (p-value $0.017 *)$; Group B vs. $\mathrm{C}$ (p-value 0.214).

Rehospitalization: Group A vs. B (p-value $\left.<0.001^{* *}\right)$; Group A vs. C (p-value $<0.001^{* *}$ ); Group B vs. C (p-value 0.067)

TVR: Group A vs B (p-value 0.147); Group A vs. C (p-value $0.035^{*}$ ); Group B vs. C (pvalue 0.377).

Symptomatic HF: Group A vs. B (p-value $\left.0.035^{*}\right)$; Group A vs. C (p-value $\left.0.0001^{* *}\right)$; Group B vs. C (p-value $\left.0.024^{*}\right)$, value $<0.05$ $\mathrm{S}$; **p-value $<0.001 \mathrm{HS}$.

Total mechanical complications: Group A vs C (p-value $0.001^{* *}$ ); Group B vs. C (pvalue $0.003 *)$.
LV aneurysm: Group A vs. C (p-value $0.035^{*}$ ); Group B vs.C (p-value $0.035^{*}$ )

Pericardial effusion: Group A vs. C (p-value 0.311); Group B vs. C (p-value 0.311).

Significant MR: Group A vs B (P-value 0.311); Group A vs. C (p-value 0.072); Group B vs.C (p-value 0.293); p-value >0.05 NS; *pvalue $<0.05 \mathrm{~S}$.

Viability after three months:

Non-viable between Group A vs. B (p-value $>0.0001^{* *}$ ); Group A vs. C (p-value $\left.<0.0001^{* *}\right)$; Group B vs. C (p-value $0.0001 * *)$; p-value $>0.05 \mathrm{NS}$; *p-value $<0.05$ $\mathrm{S} ; * *$ p-value $<0.001 \mathrm{HS}$. 


\section{MOHAMED ABD EL-MOHSEN et al.,}

\section{DISCUSSION}

Our study was planned to study the effect timing on rescue PCI short term outcome among patients with acute anterior STEMI after failed thrombolytic therapy. Patients were divided into 3 groups (A, B and C) according to time elapsed between failed thrombolysis and performing PCI to the IRA (3-6, >6-12 and $>12-24$ hours).

Our results suggest that all patients with failed fibrinolysis, defined as a persistent chest pain and/or no resolution of ST-segment elevation 60 to $90 \mathrm{~min}$ after starting I.V. administration of thrombolytic therapy, should undergo catheterization without delay, as The early the rescue PCI, the better the outcome and MACE.

Total 63 patients included in the study with mean age $58.60 \pm 10.42$ years, $(84.1 \%)$ were male and $(15.9 \%)$ were female. Diabetic patients were $(65 \%)$, hypertensives and smokers were $(65 \%$ and $42.9 \%$ respectively). All patients received standardized fibrinolysis (streptokinase; protocol of 1.5 million IU over 30-60 min intravenously) that failed.

Patients underwent rescue PCI with bare metal stents, $36.5 \%$ of patients received an additional GP IIB/IIIA inhibitor IV or intracoronary according to the operator opinion.

From TRANSFER MI trial where they studied the effect of early PCI after fibrinolysis (15\% had failed fibrinolysis ) they found that early rescue PCI had better outcome as regards MACE and it agreed with our results findings (Bagai et al., 2013).
LV function was calculated by 2D TTE using Simpson method was divided into the LV function in the acute stage and LV function after 3 months follow up.

LV function in the acute stage showed no significant difference between the groups as group (A) had mean LVEF $35.5 \%$ with a range of $(30-43)$ while group (B) mean LVEF was $35.5 \%$ (30$45 \%)$ and group (C); 34.0\% (25 - 40). While LV function after 3 months showed high significant difference between the groups with highest mean LVEF $54.1 \%$ (40 - 65) was in group A, followed by group (B) $41.5 \%(30-58)$ then group (C) $34.6 \%(20-40)$.

LV WMSI score was also obtained upon hospital stay and after 3 months follow up. LV WMSI in acute stage showed no significant difference between the groups. While LV WMSI after 3 months follow up showed significant difference between the groups with best median score in group A $(1.20 \pm 0.29)$ followed by group B $(1.62 \pm 0.32)$ and worst was in group C $(2.02 \pm 0.32)$.

Furthermore, concerning viability after 3 months follow up, there were a high significant difference between groups (pvalue $<0.001$ ). As in group A only $4.7 \%$ had non-viable IR myocardium while this percentage increased in group $\mathrm{B}$ and $\mathrm{C}$ to $38.0 \%$ and $100 \%$ respectively.

TIMI flow grade by invasive assessments in all groups showed that group A patients had the highest percentage of final TIMI flow grade III $(80.9 \%)$, while in group $\mathrm{C}$ it was only $(14.3 \%)$ with high significant difference between the groups, suggesting better final angiographic outcome with early intervention. 
These findings were in disagreement with results from TRANSFER-AMI, where there were no statistically significant difference between early or delayed PCI after thrombolysis group (whether failed or successful) regarding TIMI flow grade.

This can be explained as in TRANSFER-AMI; Tenecteplase was the thrombolytic agent used, and only $15 \%$ had failed lytic therapy (Bagai et al., 2013).

Incidence of severe and lifethreatening bleeding in our sample is $4.3 \%$ and statistically there was nonsignificant differences between groups and the higher rates of nonfatal bleeding was observed in patients who received glycoprotein IIb/IIIa receptor inhibitors (36.5\% of patients). These findings were consistent with EARLY-MYO TRIAL 2017 that studied pharmaco-invasive strategy vs primary PCI for STEMI patients and showed No significant differences in major bleeding events, or intracranial hemorrhage, but minor bleeding was significantly higher in pharmaco-invasive group $(\mathrm{Pu}$ etal., 2017).

The short term survival (within 3 months follow up ) between groups showed that group (A) had the best survival rate $(100 \%)$, whereas in group (B) and group (C) the survival rate was $(95.2 \%)$ and $(90.4 \%)$ respectively with non-significant difference in mortality between the three groups .

As regarding re-infarction and TVR rate, there was no significant difference between the 3 groups .with best result found in group (A) (0\%) and (0\%) followed by group (B) $(9.5 \%)$ and $(9.5 \%)$ and the worst was in group (C) (23.8\%), (19\%) for reinfarction and TVR respectively. Whereas the total rehospitalization was significant between groups A and B as well as between groups $\mathrm{A}$ and $\mathrm{C}$ which increased from $(0 \%)$ in group A to (47.0\%) in group B and finally $(66.6 \%)$ in group $\mathrm{C}$ while there was no statistically significant difference between group B and C .

Most of the benefit on mortality was driven by REACT (Rescue Angioplasty Versus Conservative Therapy or Repeat Thrombolysis Trial), in which $69 \%$ of patients received stent and $43 \%$ of them received GP IIb/IIIa receptor antagonists during or post PCI. In the MERLIN (Middlesbrough Early Revascularization to Limit Infarction) trial, PCI slightly but non significantly increased survival although it clearly improved event-free survival, mainly subsequent need for revascularization. Only $50 \%$ of patients underwent stent placement, and $3 \%$ of them were given IIb/IIIa inhibitors in this trial. As a consequence, there was no reduction in reinfarction as opposed to the REACT trial (Madan et al., 2015).

Chronic heart failure during the 3 months follow up showed statistically significant difference between the 3 groups with the highest percentage noted in group (C) patients (48\%) versus group (A) $(0 \%)$ and (B) $(19.0 \%)$.

Ejection fraction after 3 months follow up showed high significant difference between the 3 groups with the mean $34.6 \%(20-40)$ in group (C) versus $54.14 \%$ [40-65] in group A and 41.47 [30$58]$ in group B .

Comparing baseline Ejection fraction at presentation and after 3 months among 


\section{MOHAMED ABD EL-MOHSEN et al.,}

each group showed a highly significant difference in group A (P-value <0.001), significant difference in group $\mathrm{B}$ ( $\mathrm{P}$-value $<0.003$ ) and no significant difference was observed in group $\mathrm{C}$.

Our study agreed with MERLIN trial that enrolled 153 Patients with urgent rescue angioplasty (The mean time to rescue PCI was $85 \pm 36$ mins) that showed significant reduction in the 30-day incidence of re-infarction and heart failure.

Mechanical complications particularly LV aneurysm, significant MR as well as the VSR were significantly higher among patient who had delayed rescue PCI (total of $10 / 63$ patients $15.8 \%, 9$ of them in group C).

Our study agreed with APEX-AMI trial (Assessment of Pexelizumab in Acute Myocardial Infarction trial, 2007) that enrolled 5,745 patients with mechanical complications occurred in 52 of 5,745 patients $(0.91 \%)$. In those, PCI was done at a mean time of 23.5 hours after symptom onset and were associated with $56 \%$ (27of 52) mortality through 90 days (Martel et al., 2012).

So, early rescue PCI after failed fibrinolysis in group (A) significantly improved re-hospitalization, LVEF, viability and symptomatic heart failure as well as total mechanical complications at 3 months follows up. While intermediate and late rescue PCI (group B and group C) had significant MACE at 3 months follow up.

\section{CONCLUSION}

Our study showed that early rescue PCI after failed fibrinolysis (within 0-12 hours) constitutes the best clinical outcome for patients presenting with anterior ST elevation myocardial infarction. Major Adverse Cardiac Events (MACE; deaths, congestive heart failure, cardiogenic shock, reinfarction and TVR) has direct linear correlation with the time elapsed from failed fibrinolysis and percutaneous intervention. Short term follow-up (the 3 months) showed that there were improvement in LVEF and clinical outcome for both A \& B groups with early coronary intervention compared to group $\mathrm{C}$ with late coronary intervention. Therefore, we recommend early percutaneous coronary intervention to patients presented with anterior STEMI after failed thrombolysis for favorable clinical outcome.

\section{REFERENCES}

1. Armstrong PW, Gershlick AH, Goldstein P, Wilcox R, Danays T, Lambert Y, Sulimov V, Rosell Ortiz F, Ostojic M, Welsh RC, Carvalho AC, Nanas J, Arntz HR, Halvorsen S, Huber K, Grajek S, Fresco C, Bluhmki E, Regelin A, Vandenberghe $K$, Bogaerts $K$, Van de Werf $F$ and STREAM Investigative Team. (2013): Fibrinolysis or primary PCI in ST-segment elevation myocardial infarction. $\mathrm{N}$ Engl J Med; 368: 1379-1387.

2. Bagai A, Cantor WJ, Tan M, Tong W, Lamy A, Fitchett D, Cohen EA, Mehta SR, Borgundvaag B, Ducas J, Heffernan $M$, Dzavik V, Morrison L, Schwartz B, Lazzam C, Langer A andGoodman SG. (2013): Clinical outcomes and cost implications of routine early PCI after fibrinolysis: one-year follow-up of the Trial of Routine Angioplasty and Stenting After Fibrinolysis to Enhance Reperfusion in Acute Myocardial Infarction (TRANSFER-AMI) study. Am Heart J; 165: 630-637.e632.

3. Chakrabarti AK, Gibson CM and Pinto DS. (2012): Optimal selection of STEMI treatment strategies in the current era: benefit of transferring STEMI patients for PCI compared 
with administration of onsite fibrinolytic therapy. Curr Opin Cardiol; 27(6):651-4.

4. Farshid A, Brieger D, Hyun K, Hammett C, Ellis C, Rankin J and Lefkovits J, Chew D, French J. (2016): Characteristics and clinical course of STEMI patients who received no reperfusion in the Australia and New Zealand SNAPSHOT ACS registry. Heart Lung Circ; 25(2):132-9.

5. Madan M, Halvorsen S, Di Mario C, Tan M, Westerhout CM, Cantor WJ, Le May MR, Borgia F, Piscione F, Scheller B, Armstrong PW, Fernandez-Aviles F, Sanchez PL, Graham JJ and Yan AT, Goodman SG. (2015): Relationship between time to invasive assessment and clinical outcomes of patients undergoing an early invasive strategy after fibrinolysis for ST-segment elevation myocardial infarction: a patient-level analysis of the randomized early routine invasive clinical trials. JACC Cardiovasc Interv; 8 :16674.

6. Martel C, Granger CB, Ghitescu M, Stebbins A, Fortier A, Armstrong PW, Bonnefoy $A$ and Theroux P. (2012): Pexelizumab fails to inhibit assembly of the terminal complement complex in patients with ST-elevation myocardial infarction undergoing primary percutaneous coronary intervention. Insight from a substudy of the Assessment of Pexelizumab in Acute Myocardial Infarction (APEX-AMI) trial. Am Heart J; 164(1):43-51.

7. O'Gara PT, Kushner FG, Ascheim DD, Casey DE Jr, Chung MK, de Lemos JA, Ettinger SM, Fang JC, Fesmire FM, Franklin BA, Granger CB, Krumholz HM, Linderbaum JA, Morrow DA, Newby LK, Ornato JP, Ou N, Radford MJ, TamisHolland JE, Tommaso CL, Tracy CM, Woo YJ and Zhao DX. (2013): ACCF/AHA guideline for the management of ST-elevation myocardial infarction: a report of the American
College of Cardiology Foundation/American Heart Association Task Force on Practice Guidelines. J Am Coll Cardiol; 61:e78-e140.

8. Pu J, Ding S, Ge H, Han Y, Guo J, Lin R, Su $X$, Zhang H, Chen $L$ and He B. (2017): EARLY-MYO Investigators. Efficacy and Safety of a Pharmaco-Invasive Strategy with Half-Dose Alteplase versus Primary Angioplasty in ST-Segment-Elevation Myocardial Infarction: EARLY-MYO Trial (Early Routine Catheterization after Alteplase Fibrinolysis versus Primary PCI in Acute STSegment-Elevation Myocardial Infarction). Circulation; 136(16): 1462-1473.

9. Rosselló X, Huo Y, Pocock S, de Werf FV, Chin CT, Danchin N, Lee SW, Medina J, Vega $A$ and Bueno H. (2017): Global geographical variations in ST-segment elevation myocardial infarction management and post-discharge mortality. Int $\mathrm{J}$ Cardiol; 245:27-34.

10. Sinnaeve PR, Armstrong PW, Gershlick AH, Goldstein P, Wilcox R, Lambert Y, Danays T, Soulat L, Halvorsen S, Ortiz FR, Vandenberghe K, Regelin A, Bluhmki E, Bogaerts $K$ and Van de Werf F. (2014): STsegment-elevation myocardial infarction patients randomized to a pharmaco-invasive strategy or primary percutaneous coronary intervention: Strategic Reperfusion Early After Myocardial Infarction (STREAM) 1-year mortality follow-up. Circulation; 130 :11391145.

11. Vora, A. N., Holmes, D. N., Rokos, I., Roe, M. T., Granger, C. B., French, W. J., Antman, E., Henry, T. D., Thomas, L., Bates, E. $R$ and Wang, T. Y. (2015): Fibrinolysis use among patients requiring interhospital transfer for st-segment elevation myocardial infarction care: a report from the us national cardiovascular data registry. JAMA Intern Med. 175:207-15. 
تأثثر التوقيت علي نتائج عمل القسطرة التداخلية للثر ايين

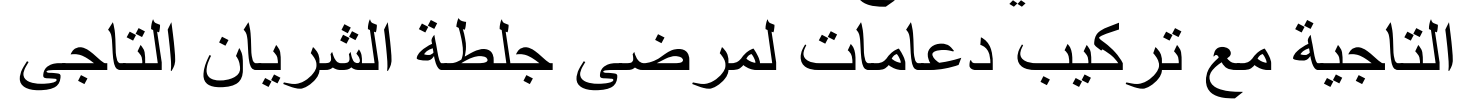
بعد فثنل عمل مذيب الجلطات على المدى القصير

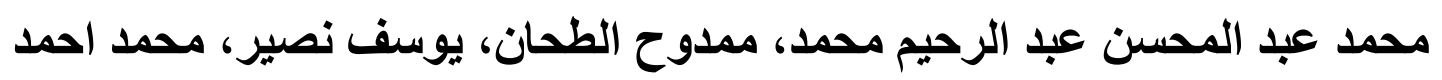

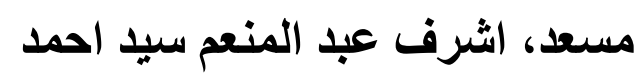

قسم القلب والاوعية الدموية والباثولوجيا الإكلينكية، كلية الطب، جامعة الأزهر ، القاهرة

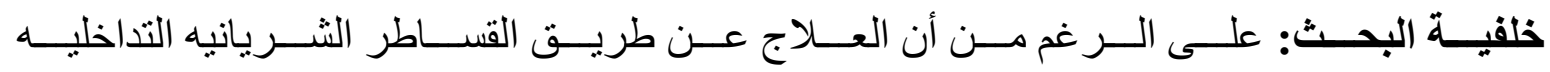

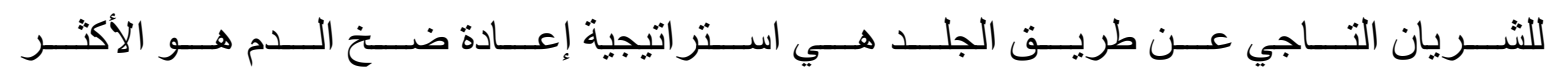

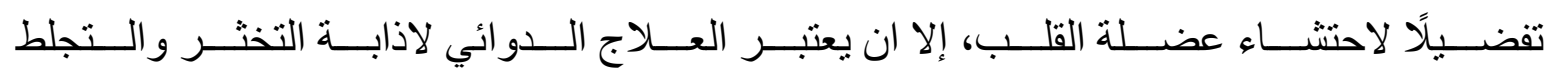

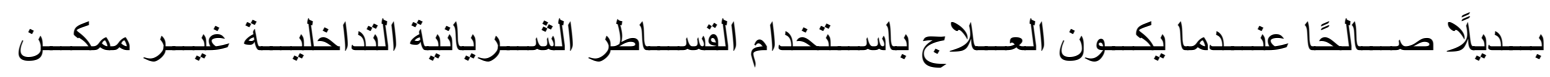
في غضون ساعة واحدة بعد الاتصال الطبي الأول.

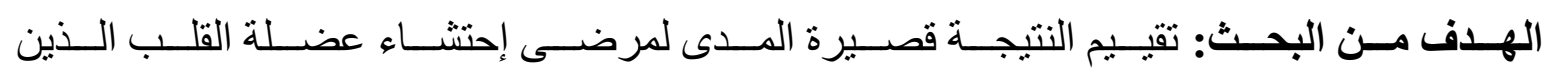

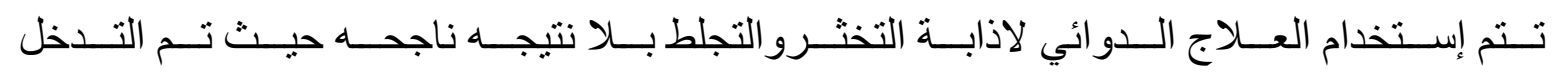

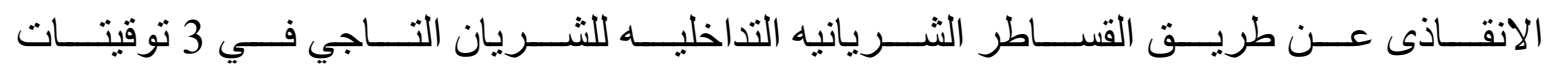

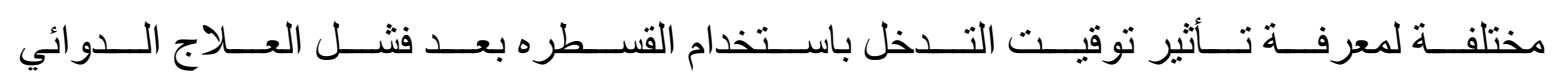
حتى 24 ساعه.

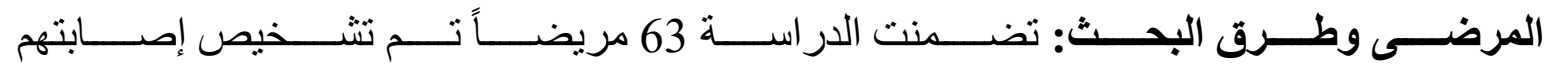

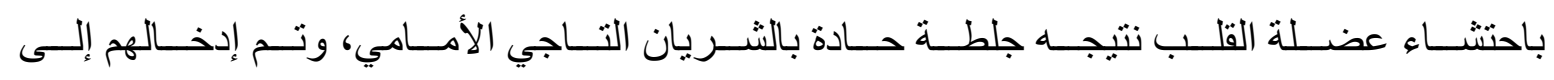

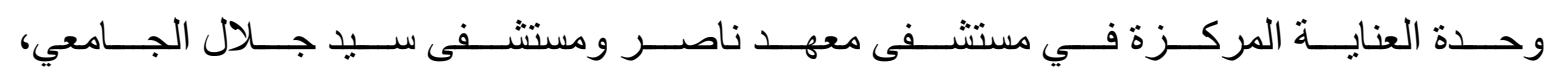

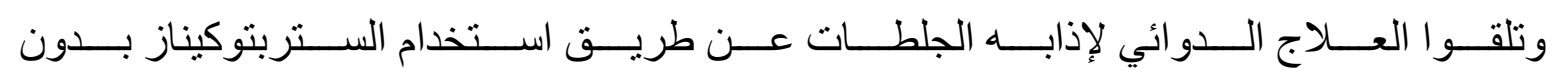

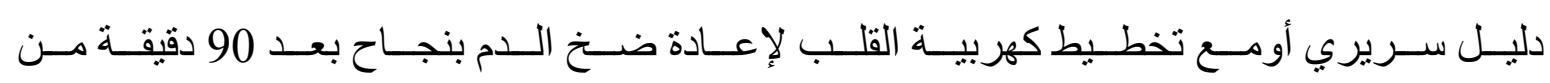

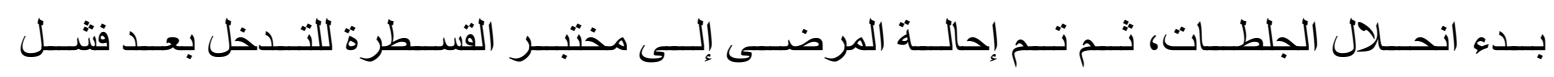
الجلطات وتم تصنيفهم إلى 3 مجمو عات متساوية:

المجموعة أ: حدث التنخل في خلال 3-6 ساعات بعد إذابة الخثرة الفاشل. المجموعة ب: حدث التدخل في خلال 6-12 ساعة بعد إذابة الخثرة الفاثل. 
المجموعه ج: حدث التدخل في خلال 12-24 ساعة بعد إذابة الخثرة الفاشل.

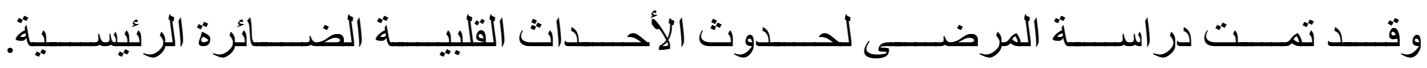

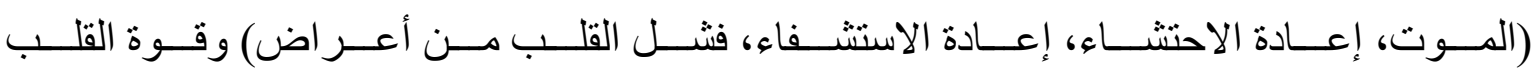

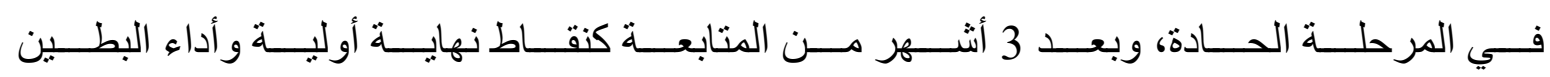

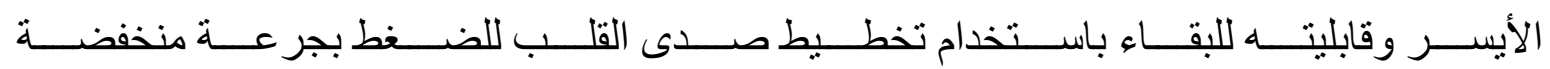
كنقاط نهاية ثانوية.

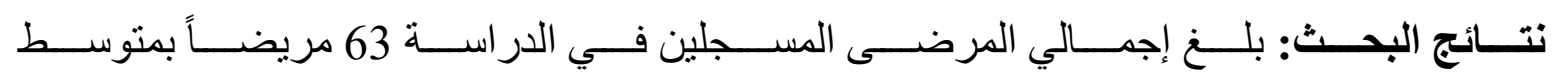

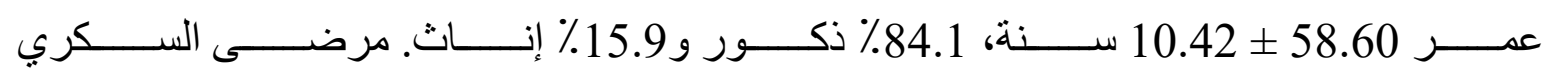

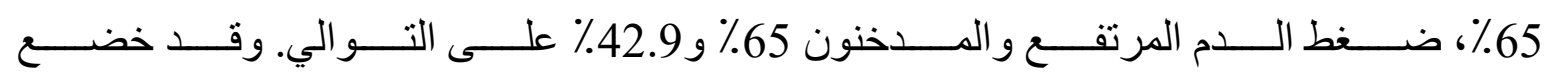

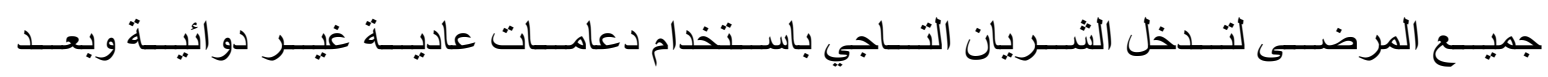

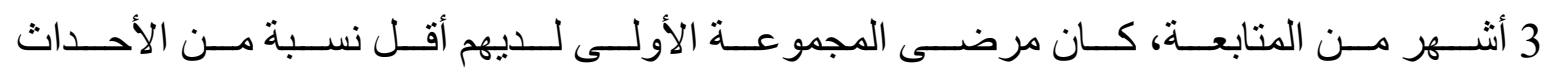

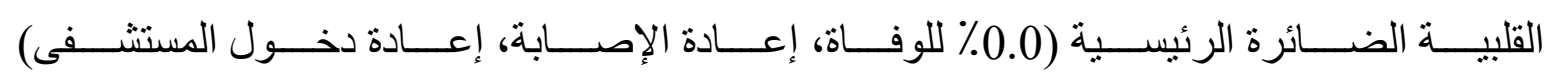

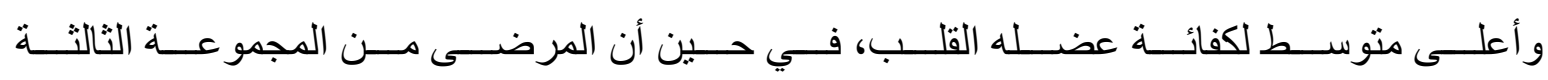

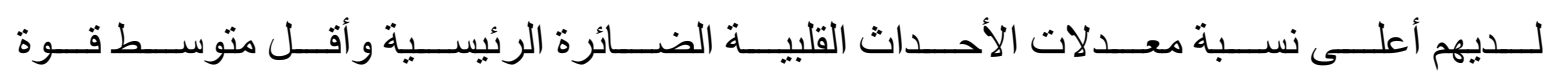

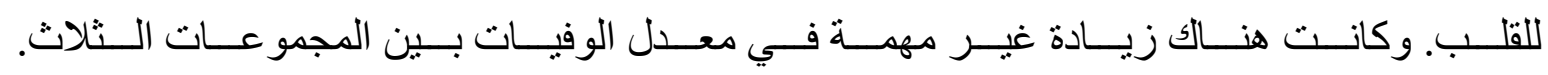

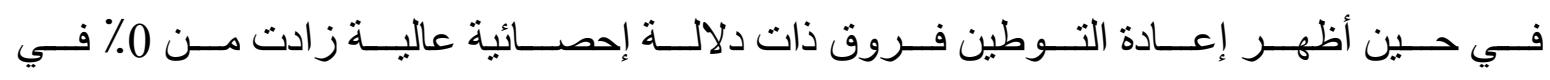
المجمو عة الأولى إلى 47.0٪ في المجمو عة الثانية و66.6\% في المجمو عة الثالثة.

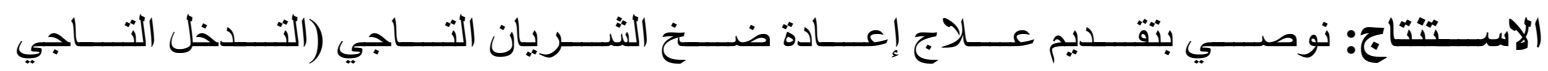

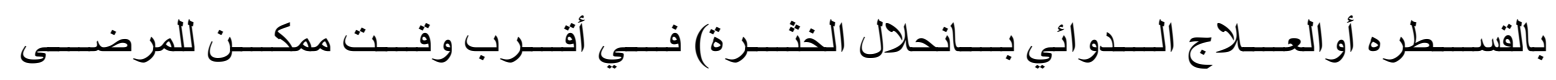

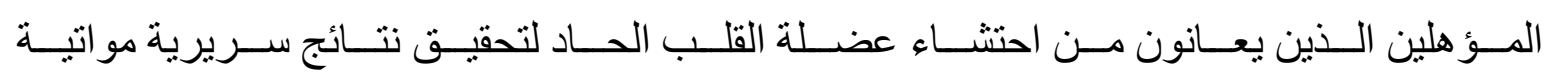
و تقليل الوفيات وحو ادث القلب الضائرة الرئيسية. 